\title{
THE ROLE OF EDUCATION IN THE KNOWLEDGE-BASED SOCIETY DURING THE ECONOMIC CRISIS
}

\author{
Ion Pârgaru ${ }^{1}$ \\ Rodica Gherghina ${ }^{2}$ \\ Ioana Duca ${ }^{3}$
}

\begin{abstract}
Education as an essential activity in the development of society has seen major transformations, from which the new methods and models of the modern educational system have resulted. The relationship between the individual and society becomes more complex via education, as the individual gains the capability to make his contribution that would balance the benefits of his living among other individuals. In this context, education represents the basis of a society oriented towards the future, knowledge becomes the main component of the economic and social growth, and the economic crisis becomes an impediment in the development of the knowledge-based society. Therefore, the development of the knowledge based society is dependent on the creation of knowledge, on its spreading via education and tuition and on its dissemination via communication and on its involvement in technological innovation.
\end{abstract}

Key words: education, knowledge-based society, economic crisis

JEL codes: H52, I21

\section{Introduction}

We are living in a society dominated by change. The technical, economical and social evolution has shaped people's way of living and thinking. The globalized markets, the technical and technological revolutions are transforming the modern economy into a "knowledge based society" in which new ways of organizing the work are governing the world, demanding a perpetual build up of competences, a rapid spread of high performance technologies, solid knowledge and increasing responsibilities. In the society of the future, education will play the key part in the way of life specific to this education and knowledge-based society. Introducing in the educational system of new learning and teaching techniques is a prerequisite of national cultural success, as much as it is also a prerequisite of economic competitiveness.

Within the current research, the authors start off from the assumption that the role of education is fundamental in the knowledge based society.

Also, the authors share the observation that the educational system is responsible for the state of the nation, and this state is conditioned by the quality of the educational system, as well as the obvious truth that the apex of high quality education today is more demanding than just forming the capacity to generate new competences. Given the economic crisis, the educational system has a major problem due to lowering financial resources, which can lead to the drop of quality and performance in the educational system and a diminished role of education in the knowledge based society. The real knowledge based society, as an expression of the globalized society, tries to connect the needs of human nature, ever growing and more and more diversified, with its own

\footnotetext{
${ }^{1}$ Titu Maiorescu University, Bucharest;

${ }^{2}$ Titu Maiorescu University, Bucharest, rodicagherghina@yahoo.com;

${ }^{3}$ Titu Maiorescu University, Bucharest, ioana.duca@utm.ro;
} 
regeneration, coming up with ways of developing the inexhaustible resources - the human intelligence, the innovative spirit, the associative creativeness, etc.

\section{Education - a fundamental activity in the knowledge based society}

Education has played and is still playing an important role in forming and training the individual throughout his existence. Several authors in their works underline the importance of education over the time.

Jean-Jacques Rousseau (1996) came up with a definition of education starting from three basic sources: nature, humans and objects. The spontaneous development of our organs and competences is education provided by nature. The day-to-day utilization of these competences is the education transmitted to us by other humans. The personal experience gained from the tools and things surrounding us, is the education provided by objects.

The Larousse dictionary (1995) defines education as the action of forming, training the individual for the purpose of applying the acquired knowledge. In the Romanian Encyclopedic Dictionary (1996), education is defined as a fundamental verbal process of transforming the life experience of children and young individuals in order to be better prepared for life, for their integration in society with benefits for the individual as well as for society.

Several authors underline the fact that "the secret of the future society is education. But not in the old-fashioned concept of teaching, but of permanent education, over the entire lifetime, in order to gain superior competences: to verify, to conceive, to create and to invent." Nowadays society, however, enforces some specific traits of the whole educational process that are anchored into the reality of the present. On a global level, education is regarded as a phenomenon, one of those activities that can favor communication through its very specific functions, as well as establishing close communication links between various countries, geographic areas and across various cultures. We cannot overlook education's role of forming and informing the individual, being a social phenomenon that in turns constitutes an important dimension of any philosophical approach of education. Education is not only about putting the individual in contact with values, but also raising him to the level of these values, than extending this process from the individual level to the society level, thus increasing its value and functionality. One of the specialists on education, Jaques Hallak (1990), stated that "education is a human right, since it leads to individual creativity, increases the participation to the economic, social, cultural activity in the society, contributing this way to the process of human development".

Education leads to lower incidence of health problems, reduced mortality and increased life expectancy. Health education, if included in the general education, tied to common organisms or other means of communication, can be more effective and less costly. In a world of evolution, of technological know-how, education plays an essential role. It is a top rank social institution that can contribute to increased democracy and equality, facilitating the rapport between man and nature.

According to A. Töffler (1995), we are living a moment in which the whole power structure that kept the world together is falling apart and a new power structure is being born, affecting the human society on every level, and this power structure is knowledge". Thus, the developed countries of the world will rapidly evolve on the coordinates of a so-called knowledge based society, and the new direction of society will be towards knowledge and learning. Given this context, education stands as the basis for a society focused at the future, and knowledge becomes the key component of economic and social growth. crisis

The importance of education in the knowledge based society during the economic

In the knowledge-based economy, the individuals need to be trained across the various levels specific to the professional forming system, adapting to the demands of the knowledge based society. The knowledge based economy and society have changed the political, economic, social 
and moral background of the world. The new society is a certainty and is one of organizations, where the primary resource is knowledge.

A knowledge based society implies a large demand of overly-qualified workforce, forcing the population to learn how to operate with information and knowledge. Therefore, the development of the knowledge based society is dependent on the creation of knowledge, on its spreading via education and tuition and on its dissemination via communication and on its involvement in technological innovation. The outlook of the societies supporting knowledge-based economies is shaped by the human creative potential, which increases the importance of the innovative process and knowledge dissemination process in the modern economy.

The link between the knowledge-based society and society itself is made by combining four interlaced elements: the build-up of knowledge, its transmission via education and training, its dissemination as information via media and its utilization in technological innovation.

The $21^{\text {st }}$ century knowledge based society tends to expand to a global proportion. Acknowledging the rapid moral depreciation of knowledge and abilities, the modern society prepares to adopt a new approach to education in order for it to function as a life-long institution of learning. In the knowledge based economy, people need to learn before entering the labor market, while in school, passing through several levels of education, as well as afterwards, adapting through various sub-systems specific to the permanent education to the increasingly complex demands of the world's dynamics.

Education as an essential activity in the development of society has seen major transformations, from which the new methods and models of the modern educational system have resulted. Furthermore, the innovative and development activities depend on the ability of the social partners to make sure that education and creativity are factors that stimulate and promote the activities carried out by the individual.

The mission of the educational system becomes a key component of change. The change is induced by several factors, the first of which must be the capability to innovate, the willingness to cooperate, to interconnect activities that are both competitive and high-performance oriented, in the sphere of knowledge, in industry and services, in the community life. The human intelligence and creativity need to be regarded as inexhaustible resources of learning and as means of integrating the human being in the labyrinth and paradox of the future world.

Changing the way of thinking is affecting not just the emotional and conceptual level, but also the actions carried out in the economic background, with direct effects on the strategically important directions of the economic policies. If during the pre-industrial and society the focus was on the classic manufacturing factors, in the knowledge based economy new sides of the human factor need to be re-discovered, after previously being quantified only as residual factors, according to some authors.

Going even further, the shift of paradigm needs to be done from the public consumption to the investment in know-how, based on the self-evident truths that education contributes to the personal development, to the social cohesion, to the productivity; it exerts a significant influence on the economic growth and reduces the social costs. Also, the professional education and training bring economic and social benefits through the increase of personal, civic, vocational competences, contribute to the development of entrepreneurship, both by creating entrepreneurial spirit as a career option, as well as by developing other specific skills. Education becomes essential to any economy, as the relationship between the individual and society becomes more complex via education, as the individual gains the capability to make his contribution that would balance the benefits of his living among other individuals.

This is why, in a society of the future, education will play an essential role in creating the new way of life specific to knowledge and learning based society. The introduction in the educational system of new teaching techniques is a prerequisite to national economic and cultural success, as well as to increased economic competitiveness. The human civilization with its new 
technologies can only exist while the focus on the elements and variables of human personality. The traits of intellectual and original creativity seem to tend to play a major role. "The immediate change is the intellectualization of the work process that puts the accent on creativity and opens a new free horizon to the decision-making process". (Töffler, 1995)

In the midterm, the forecasts show a series of priorities in terms of training and education, triggered by the availability of new technologies, thus leading to the creation of a new way of thinking and acting. According to specialists (Drucker, 1993), some of these new educational challenges are:

$>$ The school of the future should provide a top rank and universal alphabetization, which assumes understanding the basic sciences, but also an increased dynamics of learning, the study of foreign languages, so that the individual may learn ever since the school age how to act efficiently later on after entering the labor market;

$>$ Building the motivation to learn and adapt to the perpetual learning process in all individuals at all levels of the educational system;

For this purpose, the new technologies (Branden, 1996) can play a particularly important role, and the individual can advance in his path to knowledge to the point of having noticeable achievements.

$>$ Providing the information and know-how, both as a substance and as a process is a priority generated by the new technologies;

$>$ Surpassing the monopolistic condition of the school, applying a new axiom: the more educated a person gets, the more extra education they need, or at least the rerun of educational modules undertaken with unsatisfactory results in the past. This would prevent, for instance, having adults feeling overwhelmed by events.

If we consider the new educational challenges, than the new system of education needs to be an open one, conceived to ensure the equal training opportunity to all the members of society, so that the able and high-performing may have access to study in order to get a chance at social ascension, regardless of their origin, income and previous background. Furthermore, in a society of learning, often appear both the necessity of university graduates in particular to return systematically to the educational system and the necessity of any organization to continuously form its workforce, if superior results are expected to come from the work process. Learning must be a creative process, developing the capacity to solve problems.

In turns, the new technologies have the role of transforming the education by rethinking the purpose and functionality of the educational system in society. According to Drucker (1999), the people of the future will be "knowledgeable workers, service providers, trained and educated according to the society's performance criteria, able to embed in their attitude and behavior the values, the demands and the commitments of society and behave as educated people, able to influence through their knowledge and competences the present, to shape the future, being prepared to live in a global environment, where the primary resource will be knowledge".

The end purpose of the realization of a knowledge-based society is the creation of a new way of life, specific to an open society (Ciobanu, 2003). Keeping the free access to education, regardless of age or academic rank previously gained, is economic and social necessity.

In the end, "the future knowledgeable workers and service providers need to be given the chance to go to a knowledge-based work activity, to be able at any point in their life to continue their education, to make a professional orientation and re-orientation at any moment, according to the demands of the labor market" (P. Drucker, 1999, 177).

Education can provide people not only with the best technological know-how, but also by training potential innovators, to create an advance in knowledge and create economic growth. A more education population leads in turn to a more developed society. Increasing the population's level of education will also create a more stable labor market, by decreasing overall unemployment. It is well known that well educated individuals have a higher participation rate on the labor market, 
and the extent of their active lifetime is generally superior to the one of lower educational level. According to the authors, the more time is allocated to an individual's education, the better that individual is likely to face the new challenges generated by the knowledge based economy and society. In this context, the investment in education becomes the most important investment of the society and of the organizations, with long lasting results, as "the ideas, the knowledge in general, can be used and reused forever, and grow in value as they are being utilized, this contributing to the success of society".

The society based on information and knowledge assumes the intensive usage of information in all the domains of human activity and existence, with significant economic and social impact. The new information and communication technologies are used both on individual level and within organizations with high flexibility, resulting from the independence of human activity related to space and time.

Therefore, the rapid development of the IT\&C sector in the last few years has had an increasing impact on the global economy and society, bringing fundamental changes to the manufacturing and distribution models, to the occupation of the workforce and to the day-to-day life. Starting from the acknowledgement of education as a main factor in the building of knowledge based society, we see that in the context of the economic crisis, a more holistic vision is required, of an educational system placed in a world more that is more dynamic than ever, an educational system with the capacity to meet all present and future demands, which makes use of new and diversified sources of funding. The attempt to create the knowledge based society starts off successfully by bringing together the entire set of present day values that must prove the capacity of recreating the attitudes and practices of a global society. The perspective of knowledge summons and aligns the efforts towards:

$>$ Producing new knowledge through research activity;

$>$ Transferring knowledge through education and professional training;

$>$ Disseminating the knowledge by publishing;

$>$ Utilizing knowledge in the society's best interest, especially through innovation;

A society of knowledge is one in which information, regarded as a sub-component of the processes of knowing and representing reality, of conceiving and communicating, inherent to the human action on a society and organizational level, represents power in the most general level of understanding.

The informational revolution is not limited only to the IT\&C domain, but regards the very role of information plays in society; it has lead to the expansion of the frontiers of knowledge, making a decisive mark on all the components of the global system, so that obtaining, owning and making use of knowledge would become the pinnacle of a society where education plays the main role, even when society itself is passing through a profound economic crisis. This research underlines the ways in which education remains the key element in the knowledge-based society, even if in today's economic crisis it is currently facing difficulties. According to the authors, this challenge could bring about a new configuration of the educational process in a new society of the future, with different sets of values.

\section{Conclusions}

To conclude the article, throughout the world, the roles of education and of its multiple benefits to the economic and social environment are well known, as education is recognized as being "the single most important path to development and to limiting poverty". The increasing extent of services in the economy, the pace of technological changes, the advanced level of information and knowledge, as well as the size of the industrial and social re-organizations, all give good arguments in favor of the knowledge based society. The main component of economic and social development becomes knowledge. 
In other words, the basis of the future society is education (perpetual, life-long educative process) and knowledge and information represent the key variables in the development of society.

During the development process, the contribution of education and professional training are essential, their funding needs to be recognized as being of maximum importance and today's economic crisis demands identifying new funding mechanisms resulting from the partnership between the companies and the public sector. In the knowledge-based society the mission of the educational system becomes a key component of change.

\section{References:}

1. Branden, N., 1996. The Seven Pillars of Self Respect. Ed. Colosseum

2. Ciobanu, O., 2003. Romania's Economic Education - Present and Perspectives, Academy of Economic Studies Publishing House. Bucharest

3. Drucker, F. P., 1999. Post Capitalist Society, Image Publishing House. Bucharest

4. Drucker, F. P., 1999. The New Realities. Teora Publishing House. Bucharest

5. Roşca, I., Gh., et al 2006. The Knowledge-Based Society, Economic Publishing House. Bucharest

6. Hallak, J., 1990. Investir dans l'avenir. Définir les priorités de l'education dans le monde en développement. Editions L'Harmattan. Paris

7. Rousseau, J. J., 1996. Social Contract (1762). Moldova Publishing House. Iaşi,

8. Suciu, M. C., 2000. Investment in Education. Economic Publishing House. Bucharest

9. Töffler, A., 1995. Power in motion. Antet Publishing House. Bucharest

10. De la Fuente, A., Ciccone, A., 2002. Human capital and growth in a global and knowledge-based economy. Report for the European Commission, DG for Employment and Social Affairs

11. Comunicarea Comisiei Europene, 2003. Efficient Investment in Education and professional training: a top priority for Europe. Bruxelles

12. Petit Larrousse, 1995. Dictionaire Enciclopedique Larrousse. Paris

13. Dicţionar enciclopedic, vol. II, 1996. Encyclopedic Publishing House. Bucureşti 